\title{
POLITIK HUKUM PERTAMBANGAN MINERAL DAN BATUBARA SAAT BERLAKU UNDANG-UNDANG NOMOR 23 TAHUN 2014 TENTANG PEMERINTAHAN DAERAH
}

\author{
Fine Ennandrianita \\ Email: fn.ennandrian@gmail.com \\ Mahasiswa Program Magister Ilmu Hukum Program Pascasarjana \\ Fakultas Hukum Universitas Sebelas Maret Surakarta \\ Isharyanto \\ Email: masis_uns@yahoo.com \\ I Gusti Ayu Ketut Rachmi Handayani \\ Email: ayu_igk@staff.uns.ac.id \\ Dosen Fakultas Hukum Universitas Sebelas Maret Surakarta
}

\begin{abstract}
This paper discusses the legal politics of mineral and coal mining, as well as the authority of the goverment in managing the natural resources of mineral and coal mining. Mineral and coal mining is a non-renewable natural resource, so for the sake of sustainability the government's role in management, coaching and supervision is needed. Major Changes occured since the enactment of law No. 23 of 2014 on Regional Goverment which regulates the distribution of goverment affairs. The existence of the Law makes the authority of the management of mineral and coal mining in the Regional Government of Regency or City to be abolished This research is a prescriptive legal research with a legal approach and a conceptual approach.This paper is a presciptive legal research with approach of law and conceptual approach. The technique of collecting legal materials in this paper is literature study. The technique of analysis of legal materials used is the method of deduction. This paper concludes the existence of disharmonization between sectoral regulations and local government laws in 2014 and the legal consequences of the enactment of the Regional Government Law in the form of (i) institutional change, (ii) personnel handover, funding, facilities and infrastructure, (P3D), (iii) amendment of laws and regulations.
\end{abstract}

Keywords: legal politics, mineral and coal mining, patient, enactment of law No. 23 of 2014 on Regional Goverment

Abstrak
Tulisan ini membahas politik hukum pertambangan mineral dan batubara serta
kewenangan pemerintah dalam mengelola sumber daya alam pertambangan mineral
dan batubara. Pertambangan mineral dan batubara merupakan sumber daya alam yang
tidak dapat diperbaharui, sehingga demi keberlangsungan diperlukan peran 
pemerintah dalam hal pengelolaan, pembinaan dan pengawasan. Perubahan besar terjadi sejak diberlakukan Undang-Undang Nomor 23 Tahun 2014 tentang Pemerintahan Daerah, yang mengatur mengenai pembagian urusan pemerintahan. Keberadaan Undang-Undang tersebut membuat kewenangan pengelolaan pertambangan mineral dan batubara di Pemerintah Daerah Kabupaten/ Kota menjadi hapus. Penelitian ini merupakan penelitian hukum yang bersifat preskiptif dengan pendekatan undang-undang dan pendekatan konseptual. Teknik pengumpulan bahan hukum studi pustaka dan teknik analisis bahan hukum metode deduksi. Hasil tulisan ini menyimpulkan adanya disharmonisasi antara peraturan perundangan sektoral dengan UU Pemda 2014 dan adanya konsekuensi hukum terhadap pemberlakuan UU Pemda berupa (i) perubahan kelembagaan; (ii) serah terima personil, pendanaan , sarana dan prasarana, dan dokumen $(\mathrm{P} 3 \mathrm{D})$; (iii) perubahan peraturan perundangundangan.

Kata kunci: politik hukum, pertambangan mineral dan batubara, undang-undang nomor 23 tahun 2014 tentang pemerintahan daerah.

\section{A. Pendahuluan}

Ketentuan Pasal 18 Undang-Undang Dasar 1945, merupakan dasar hukum pembentukan Pemerintahan Daerah dan penyelenggaraan otonomi daerah dengan memberikan kewenangan yang luas, nyata dan bertanggung jawab kepada Daerah. Undang-Undang Dasar Negara Republik Indonesia Tahun 1945 selanjutnya UUD 1945, telah mengamanatkan suatu bentuk Pemerintahan Daerah, yang mengatur dan mengurus sendiri urusan pemerintahan menurut asas otonomi dan tugas pembantuan (Lili Romli, 2007:8).

Namun demikian, amanat pelaksanaan Pemerintahan Daerah melalui kebijakan desentralisasi dalam praktik implementasinya tidaklah mudah. Perbedaan kondisi geografis dan demografis dapat menimbulkan banyak permasalahan dalam pelaksanaan otonomi daerah. Pada dasarnya pembentukan daerah dimaksudkan untuk

meningkatkan kemandirian pada daerah serta sebagai pelayanan publik guna mempercepat terwujudnya kesejahteraan masyarakat disamping sebagai sarana pendidikan politik di daerah.

Penyelenggaraan otonomi daerah diatur dalam urusan pemerintahan yang terdapat pada Undang-Undang Nomor 23 Tahun 2014 Tentang Pemerintahan Daerah 
(selanjutnya UU Pemda 2014), yang telah mengalami dua kali perubahan yaitu Undang-Undang Nomor 2 Tahun 2015 Tentang Perubahan Pertama Undang-Undang Nomor 23 Tahun 2014 Tentang Pemerintahan Daerah, dan Undang-Undang Nomor 9 Tahun 2015 Tentang Perubahan Kedua Undang-Undang Nomor 23 Tahun 2014 Tentang Pemerintahan Daerah.

Penyelenggaraan Urusan Pemerintahan pada UU Pemda 2014 dilaksanakan berdasarkan asas desentralisasi, asas dekonsentrasi, dan asas tugas pembantuan. Urusan pemerintahan terdiri atas urusan pemerintahan absolut, urusan pemerintahan konkuren, dan urusan pemerintahan umum. Pengaturan urusan pemerintahan konkuren meberikan dampak perubahan yang besar terhadap pengelolaan Sumber Daya Alam (selanjutnya SDA). UU Pemda 2014 menarik banyak urusan pemerintahan yang pernah dilimpahkan pada Kabupaten/Kota. Lewat UU Pemda 2014, kewenanan pengelolaan SDA di Kabupaten/ Kota di beberapa sektor, diantanya adalah bidang kelautan dan perikanan, kehutanan serta energi dan sumber daya mineral menjadi hapus.

Selanjutnya urusan pemerintahan bidang ESDM yang berkaitan dengan pengelolaan pertambangan mineral dan batubara (selanjutnya minerba) menjadi kewenangan Pemerintah Pusat dan Pemerintah Daerah Provinsi. Hal tersebut diatur lebih lanjut pada lampiran huruf CC UU Pemda 2014. Dengan demikian kewenangan Peemrintah Kabupaten/Kota yang hilang diantaranya adalah membuat Perda terkait ESDM, pemberian izin usaha pertambangan, pembinaan dan pengawasan. Penempatan pengelolaan SDA dalam kebijakan desentralisasi, tidak terlepas dari kedudukan SDA sebagai sumberdaya yang mendatangkan kemampuan finansial negara untuk menyelenggarakan pelayanan dasar. Sebagai produk politik, SDA dalam peraturan perundang-undangan mengenai desentralisasi juga merupakan hasil dari kompromi dalam proses pengambilan kebijakan public/ public policy making (Rikardo Simarmata dan Asep Yunan Firdaus, 2016: 6).

Hal lain yang menarik untuk dikaji dalam UU Pemda 2014 adalah terkait kebijakan di bidang pertambangan minerba. Kemunculan UU Pemda 2014 dengan 
corak sentralistik menyisakan tanda tanya mengenai dampaknya terhadap undangundang sektoral di bidang sumberdaya alam seperti Undang-Undang Nomor 4 Tahun 2009 Tentang Pertambangan Mineral dan Batubara (Selanjutnya UU Minerba ).

Ketentuan dalam UU Minerba sebagai UU sektoral yang mengatur kegiatan pertambangan minerba, mempertegas kendali dan juga tanggungjawab dalam pengelolaan minerba. Pasal 4 ayat (1) UU Minerba disebutkan "Mineral dan batubara sebagai sumber daya alam yang tak terbarukan merupakan kekayaan nasional yang dikuasai oleh negara untuk sebesar-besar kesejahteraan rakyat". Selanjutnya ayat (2) diterangkan "Penguasaan mineral dan batubara oleh negara sebagaimana dimaksud pada ayat (1) diselenggarakan oleh Pemerintah dan/atau pemerintah daerah".

Ketentuan Pasal 4 ayat (1) dan ayat (2) menegaskan bahwa tanggung jawab serta penyelenggaraan penguasaan minerba oleh Pemerintah Pusat dan Pemerintah Daerah Provinsi/ Kabupaten/Kota. Selain itu dalam pasal tersebut juga menjelaskan bahwa kewenangan melakukan pengelolaan pertambangan minerba berada di Pemerintahan Pusat dan Daerah Provinsi/ Kabupaten/Kota. Hal tersebut tentu berbenturan dengan ketentuan yang terdapat pada UU Pemda 2014, dimana kewenangan pengelolaan pertambangan minerba berada pada Pemerintah Pusat dan Pemerintah Daerah Provinsi. Sedangkan Pemerintah Daerah Kabupaten/ Kota tidak memilili kewenangan dalam hal pengelolaan pertambangan minerba.

Kajian ini, yang menitikberatkan pada review peraturan perundang-undangan, bermaksud menggambarkan mengenai politik hukum bidang pertambangan minerba, termasuk didalamnya akan dibahas mengenai harmonisasi UU Pemda 2014 dan UU Minerba. Selain itu juga akan diteliti mengenai konsekuensi hukum dari perubahan kewenangan bidang pertambangan minerba saat berlakuknya UU Pemda 2014.

\section{B. Metode Penelitian}

Penelitian ini adalah penelitian hukum doktrinal yang menggunakan metode studi kepustakaan. Bahan hukum yang digunakan adalah bahan hukum primer yang 
meliputi peraturan perundang-undangan mulai dari Undang-Undang Dasar Negara Republik Indonesia Tahun 1945, Undang-Undang, dan peraturan perundangundangan lainnya yang terkait dengan masalah penelitian. Sumber informasi hukum mencakup juga bahan hukum sekunder seperti buku-buku referensi, majalah hukum, jurnal hukum, surat kabar, dan hasil karya ilmiah yang relevan dengan topik penelitian (Peter Mahmud Marzuki, 2014: 237-240).

\section{Hasil Penelitian Dan Pembahasan}

1. Politik Hukum Pengelolaan Pertambangan Mineral dan Batubara

Pertambangan yaitu suatu kegiatan yang dilakukan dengan penggalian ke dalam tanah (bumi) untuk mendapatkan sesuatu yang berupa hasil tambang (Gatot Supramono, 2012:6). Ketentuan Pasal 1 angka 1 UU Minerba menjelaskan bahwa: "Pertambangan adalah sebagian atau seluruh tahapan kegiatan dalam rangka penelitian, pengelolaan dan pengusahaan mineral atau batubara yang meliputi penyelidikan umum, eksplorasi, studi kelayakan, konstruksi, penambangan, pengolahan dan pemurnian, pengangkutan dan penjualan, serta kegiatan pascatambang." Pengertian tersebut dalam arti luas karena meliputi berbagai kegiatan pertambangan yang ruang lingkupnya dapat dilakukan sebelum penambangan, proses penambangan, dan sesudah proses penambangan.

Ada dua hal yang diatur dalam UU Minerba, yaitu bahan tambang mineral dan batubara. Salim HS menyatakan Hukum Pertambangan merupakan salah satu bidang kajian hukum yang mengalami perkembangan yang pesat. hal ini dibuktikan dengan ditetapkannya berbagai peraturan perundang-undangan yang mengatur tentang pertambangan. Pada dekade tahun 1960-an, undangundang yang mengatur tentang pertambangan, yaitu Undang-Undang Nomor 11 Tahun 1967 tentang Ketentuan-Ketentuan Pokok Pertambangan, sementara pada dekade tahun 2000 atau khususnya pada tahun 2009, maka Pemerintah 
dengan persetujuan DPR RI telah menetapkan Undang-Undang Nomor 4 Tahun 2009 tentang Pertambangan Mineral dan Batubara (Salim H.S , 2014:11).

Pulau Sumatera memiliki kekayaan alam hasil tambang berupa minyak bumi, batu bara, tembaga, timah, granit, dan beberapa hasil tambang lainnya. Pulau Kalimantan menyimpan kekayaan tambang berupa batu bara dan minyak bumi. Pulau Jawa yang memiliki hasil tambang berupa minyak bumi, bijih besi, granit, dan hasil tambang lainnya. Di Pulau Sulawesi tersebar hasil tambang mangaan, fosfat, tembaga, nikel, dan beberapa hasil tambang lainnya, dan di pulau paling timur di Indonesia yaitu Papua menyimpan kekayaan tambang minyak bumi, emas, perak, tembaga dan beberapa hasil tambang lainnya (Victor Imanuel, 2012: 474).

Mineral dan batubara yang terkandung dalam wilayah hukum pertambangan Indonesia merupakan kekayaan alam tak terbarukan sebagai karunia Tuhan Yang Maha Esa yang mempunyai peranan penting dalam memenuhi hajat hidup orang banyak, karena itu pengelolaannya harus dikuasai oleh Negara untuk memberi nilai tambah secara nyata bagi perekonomian nasional dalam usaha mencapai kemakmuran dan kesejahteraan rakyat secara berkeadilan. Berdasarkan pasal 33 ayat (3) dan ayat (4) UUD 1945, negara diberikan kewenangan oleh UUD 1945 untuk menguasai SDA dalam rangka sebesar-besarnya kemakmuran rakyat. Hak penguasaan negara berisi wewenang untuk mengatur, mengurus dan mengawasi pengelolaan atau pengusahaan pertambangan serta berisi kewajiban untuk mempergunakannya sebesarbesarnya bagi kemakmuran rakyat.

Secara normatif politik hukum pengelolaan sumber daya alam di Indonesia sudah ditentukan dalam Pasal 33 ayat (2) dan ayat (3) UUD 1945. Pasal 33 ayat (2) berbunyi "Cabang-cabang produksi yang penting bagi negara yang menguasai hajat hidup orang banyak dikuasai negara”. Pasal 33 ayat (3) berbunyi "Bumi dan air dan kekayaan alam yang terkandung 
didalamnya dikuasai oleh negara dan digunakan untuk sebesar-besar kemakmuran rakyat”.

Kajian dalam Pasal 33 UUD 1945 merupakan dasar dalam pengelolaan pertambangan yang bertujuan untuk menciptakan keadilan. Namun keadilan dalam Pasal 33 UUD 1945 lebih bermotif keadilan ekonomi daripada keadilan ekologi. Sehingga dengan berdasarkan pada Pasal $28 \mathrm{H}$ UUD 1945 yang menyatakan bahwa "Setiap orang berhak hidup sejahtera lahir dan batin, bertempat tinggal, dan menempatkan lingkungan hidup yang baik dan sehat serta berhak memperoleh pelayanan kesehatan" dimaknai bahwa hak atas lingkungan yang baik dan sehat adalah bagian dari hak asasi manusia disamping hak asasi manusia yang lain.

Negara sebagai pemegang hak pengelola berdasar pada Pasal 33 ayat (2) dan (3) UUD 1945 harus berpihak kepada kepentingan bangsa. Ideologi keberpihakan negara kepada kepentingan bangsa ditegaskan lebih lanjut dalam Pasal 2 Undang-Undang Minerba yang menyatakan bahwa Pertambangan mineral dan/atau batubara dikelola berasaskan:

a. manfaat, keadilan, dan keseimbangan;

b. keberpihakan kepeda kepentingan bangsa;

c. partisipatif, transparansi, dan akuntabilitas;

d. berkelanjutan dan berwawasan lingkungan.

Meskipun asas keberpihakan negara kepada kepentingan bangsa sudah tertulis di dalam UU Minerba, akan tetapi dalam penjelasan undang-undang tersebut tidak menjelaskan makna dan hakekat dari asas keberpihakan kepada kepentingan bangsa. Sehingga makna dan hakekat dari asas keberpihakan negara kepada kepentingan bangsa tidak jelas. Kelemahan dari UU Mineba adalah belum mempunyai undang-undang payung sebagai pengawas yang memperjelas keberpihakan negara kepada kepentingan bangsa. Tujuan dari UU Minerba adalah memberikan nilai tambah secara nyata kepada 
pertumbuhan ekonomi nasional dan pembangunan nasional secara berkelanjutan.

Penguasaan bahan galian tidak hanya menjadi monopoli pemerintah semata-mata, tetapi juga diberikan hak kepada orang dan/atau badan hukum untuk mengusahakan bahan galian sehingga secara optimal. Agar orang atau badan hukum dapat mengusahakan pertambangan minerba, Pemerintah Pusat dan Daerah Provinsi, Kabupaten/ Kota selayaknya dapat memberikan izin kuasa pertambangan sebagaimana diatur dalam UU Minerba. Namun sejak berlaku UU Pemda 2014, kewenangan Pemerintah Daerah Kabupaten/ Kota untuk menerbitkan kuasa izin pertambangan menjadi hapus.

2. Harmonisasi Kewenangan Daerah Bidang Pengelolaan Pertambangan Mineral dan Batubara

Istilah harmonisasi dalam kajian berasal dari kata harmoni (bahasa Yunani harmonia), yaitu terikat secara serasi dan sesuai. Ditinjau dari aspek filsafat, harmoni diartikan kerja sama antara berbagai faktor yang sedemikian rupa sehingga faktor-faktor tersebut menghasilkan kesatuan yang luhur, misalnya antara jasad seorang manusia hendaknya harus ada harmoni, kalau tidak belum dapat disebut pribadi (Hassan Shadly, 1980: 1262).

Harmonisasi peraturan perundang-undangan merupakan keserasian antara peraturan perundang-undangan antara yang satu dengan yang lainnya, baik yang berbentuk vertikal (hierarki perundang-undangan) ataupun horizontal (perundang-undangan yang sederajat). Keserasian tersebut, yakni tidak ada pertentangan antara peraturan yang satu dengan yang lainnya, akan tetapi peraturan yang satu dengan yang lainnya saling memperkuat ataupun mempertegas dan memperjelas (Mohammad Zamroni, 2015: 375).

Buku Tussen en verscheidenheid: Opstellen over harmonisatie in staatsen bertuursrecht sebagaimana di kutip LM Gandhi mengemukakan, harmonisasi dalam hukum adalah mencakup penyesuaian, peraturan perundangundangan, keputusan pemerintah, keputusan peningkatan kesatuan hukum, 
kepastian hukum keadilan (justice, gerechtigheid) dan kesebandingan (equity, billijkheid), kegunaan dan kejelasan hukum, tanpa mengaburkan dan mengorbankan pluralisme hukum kalau memang dibutuhkan (L.M Gandhi, 1995). Oleh karena itu, yang dimaksud harmonisasi perundang-undangan adalah upaya atau proses untuk merealisasi keselarasan dan keserasian asas dan sistem hukum sehingga menghasilkan peraturan yang harmonis. Dengan kata lain pengharmonisan merupakan upaya untuk menyelaraskan, menyesuaikan, menetapkan dan membulatkan konsepsi suatu peraturan perundang-undangan lain baik yang lebih tinggi (superior), sederajat, maupun yang lebih rendah (inferior) dan lain-lain selain peraturan perundang-undangan, sehingga tersusun secara sistematis, tidak saling bertentangan atau tumpang tindih (overlaping).

Harmonisasi menurut Oka Mahendra (AA. Oka Mahendra, 2013:178) idealnya dilakukan pada saat perancangan peraturan perundang-undangan. Pengharmonisasian rancangan undang-undang mencakup 2 (dua) aspek yaitu:

a. Pengharmonisasian materi muatan rancangan undang-undang dengan Pancasila, UUD 1945( harmonisasi vertikal), Undang-Undang (harmonisasi horizontal) dan asas-asas peraturan perundang-undang;

b. Pengharmonisasian rancangan undang-undang dengan teknik penyusunan peraturan perundang-undangan yang meliputi kerangka peraturan perundang-undangan, hal-hal khusus, ragam bahasa dan bentuk rancangan peraturan perundang-undang.

Kesesuaian norma hukum yang lebih rendah dengan yang lebih tinggi juga nampak dalam sejumlah asas yang dikenal dalam ilmu hukum. Asas-asas tersebut biasanya dipergunakan dalam menyelesaikan konflik norma hukum. P.W. Brouwer dalam Armen menyebutkan asas-asas hukum umum atau prinsip hukum (general principles of law) yang harus diperhatikan dalam pembentukan peraturan perundang-undangan yaitu: (Armen Yasir, 2007: 60-61)

a. Asas lex superior derogat legi inferiori, yaitu peraturan perundangundangan yang lebih tinggi tingkatannya didahulukan berlakunya 
daripada peraturan perundang-undangan yang lebih rendah dan sebaliknya peraturan perundang-undangan yang lebih rendah tidak boleh bertentangan dengan peraturan perundang-undangan yang lebih tinggi tingkatannya.

b. Asas lex specialis derogat legi generali, yaitu peraturan perundangundangan khusus didahulukan berlakunya daripada peraturan perundang-undangan yang umum. Prinsip ini berlaku terhadap peraturan perundang-undangan yang setingkat.

c. Asas lex posterior derogat legi priori, yaitu peraturan perundangundangan yang baru didahulukan berlakunya daripada yang terdahulu.

d. Asas lex neminem cogit ad impossobilia, yaitu peraturan perundangundangan tidak memaksa seseorang untuk melakukan sesuatu yang tidak mungkin dilakukan atau sering disebut dengan asas kepatutan (bilijkheid).

e. Asas lex perfecta, yaitu peraturan perundang-undangan tidak saja melarang suatu tindakan tetapi juga menyatakan tindakan terlarang itu batal.

f. Asas non retroactive, yaitu peraturan perundang-undangan tidak dimaksudkan untuk berlaku surut (statues are not intended to have retroactive effect) karena akan menimbulkan ketidakpastian hukum.

Menjadi permasalahan baru saat ini adalah tumpang tindihnya peraturan mengenai pembagian urusan pemerintahan antara pusat dan daerah dan siapa yang berwenang mengeluarkan Izin Usaha Pertambangan (selanjutnya IUP). UU Pemda 2004 yang merupakan salah satu latar belakang dan dasar penetapan aturan mengenai penerbitan IUP yang diatur dalam UU Minerba, telah diganti dengan UU Pemda 2014. Hal ini menyebabkan adanya ketidak sinkronan yang berakhir pada rancunya pihak yang berwenang dalam pengelolaan, pemberian izin, pengawasan dan pembinaan SDA pertambangan minerba. 
Secara garis besar UU Minerba mengatur mengenai kewenangan di daerah yaitu Pemerintah Daerah Kabupaten/ Kota, dalam pola penyelenggaraan Pemerintahan dalam kewenangan pengelolaan ESDM khususnya mengenai penerbitan IUP dilakukan oleh Bupati/ Walikota. Ketentuan dalam UU Minerba untuk kebijakan yang dilakukan Pemerintah Pusat memiliki kapasitas berupa tanggung jawab mengatur penetapan kebijakan dan pengaturan, penerapan standar dan pedoman, penetapan kriteria pembagian urusan Pemerintah Pusat dan Daerah, tanggung jawab pengelolaan pertambangan minerba berdampak nasional dan lintas provinsi.

Sedangkan kewenangan Pemerintah Daerah Provinsi bertanggung jawab terhadap pengelolaan minerba lintas kabupaten yang berdampak regional. Selanjutnya Kewenangan Pemerintah Daerah Kabupaten berfungsi untuk pengelolaan pertambangan minerba di wilayah Kabupaten/ Kota. Dengan demikian kewenangan Pemerintah Daerah Kabupaten/ Kota masih cukup kuat dalam pengelolaan dan kebijakan SDA mineral dan batubara.

Lain hal terhadap ketentuan UU Pemda 2014, memiliki pandangan dan semangat penyelenggraan kewenangan pemerintahan terkait pengelolaan SDA yang didalamnya bidang pertambangan minerba. Dengan keluarnya UU Pemda 2014 kebijakan dan kewenangan Pemerintah Daerah Kabupaten/ Kota terkait pengelolaan pertambangan minerba dan kewenangan memberikan izin pertambangan minerba dialihkan ke Pemerintah Daerah Provinsi dan Pemerintah Pusat. Pembinaan dan pengawasan terhadap penyelenggraan pemerintahan daerah diatur secara jelas dengan berbagai instrumen seperti evaluasi, klarifikasi, persetujuan, dan bentuk lainnya. Peran Gubernur sebagai wakil Pemerintah Pusat dipertegas dan diperkuat dalam melakukan pembinaan dan pengawasan terhadap Pemerintah Daerah Kabupaten/ Kota.

Disharmonisasi antara UU Pemda 2014 dengan UU Minerba tersebut mengakibatkan terjadinya tumpang tindih kewenangan. Dalam UU Minerba pemerintah Kabupaten/Kota memiliki wewenang untuk mengeluarkan IUP, 
namun dalam UU Pemda 2014 wewenang hanya dimiliki oleh Pemerintah Pusat dan Daerah Provinsi. Disharmoni antara UU Minerba dan UU Pemda 2014 adalah disharmoni horizontal yaitu pertentangan antara peraturan perundang-undangan yang sederajat dalam hierarki. Pertentangan ketentuan dalam UU Pemda 2014 dengan UU Minerba tersebut merupakan inkonsistensi dari segi substansi peraturan, yakni peraturan yang secara hierarkis sejajar tetapi substansi peraturan yang satu lebih umum dibandingkan substansi peraturan lainnya.

Pada konteks disharmoni antara ketentuan dalam UU Pemda 2014 dengan UU Minerba, untuk menyelesaikannya dapat digunakan asas preferensi. Asas preferensi lex specialis derogat legi generali adalah asas preferensi yang tepat digunakan dalam konteks ini. Harmonisasi peraturan perundang-undangan dengan asas lex specialis derogat legi generali merujuk pada dua peraturan perundang-undangan yang secara hierarkis mempunyai kedudukan yang sama, tetapi ruang lingkup materi muatan antara peraturan perundang-undangan itu tidak sama, yaitu yang satu merupakan pengaturan secara khusus dari yang lain.

Aturan hukum yang memuat asas lex specialis derogate legi generali dilihat menurut teori sistem hukum dari Hart, termasuk kategori rule of recognition, yang mengatur aturan hukum mana yang diakui sah sebagai suatu aturan yang berlaku. Asas lex specialis derogat legi generali merupakan asas hukum yang menentukan dalam tahap aplikasi (application policy), sehingga dikatakan sebagai asas yang menentukan aturan hukum mana yang berlaku.

Bagir Manan mengemukakan beberapa prinsip yang harus diperhatikan dalam asas lex specialis derogat legi generali, yaitu:

a. Ketentuan-ketentuan yang didapati dalam aturan hukum umum berlaku, kecuali yang diatur khusus dalam aturan hukum khusus tersebut

b. Ketentuan-ketentuan lex specialis harus sederajat dengan ketentuanketentuan lex generali 
c. Ketentuan-ketentuan lex specialis harus berada dalam lingkungan hukum yang sama dengan lex generali (Bagir Manan, 2004: 56)

Pada konteks pertentangan antara UU Pemda 2014 dengan UU Minerba mengenai penerbitan IUP, UU Minerba mengatur substansi yang lebih khusus dan spesifik mengenai penerbitan IUP jika dibandingkan dengan UU Pemda 2014. Berdasarkan segi substansinya, UU Minerba merupakan aturan hukum khusus, sementara UU Pemda 2014 merupakan aturan hukum umumnya. Ketentuan dalam UU Minerba dengan UU Pemda 2014 juga berada dalam pengaturan mengenai ketentuan yang sama, yakni kewenangan penerbitan IUP. Hanya saja, ketentuan dalam UU Minerba lebih spesifik dibandingkan dengan UU Pemda 2014. Kedudukan UU Minerba dengan UU Pemda 2014 pun sederajat, karena keduanya sama-sama berbentuk dalam undang-undang. Ketiga prinsip-prinsip penggunaan asas lex specialis derogat legi generali tersebut terpenuhi, ini berarti asas preferensi lex specialis derogat legi generali dapat diterapkan untuk menyelesaikan disharmoni yang terjadi di antara UU Pemda 2014 dengan UU Minerba mengenai kewenangan penerbitan IUP.

Merujuk pada UU Pemda 2014 disebutkan secara jelas bahwa titik berat pembagian suatu urusan pemerintahan hendaknya menggunakan prinsip subsidiaritas, yakni diletakkan pada yang letaknya lebih dekat dengan berbagai aspek penyelenggaraan urusan pemerintahan tersebut. Dengan menitikberatkan prinsip subsidiaritas, maka kewenangan pemberian IUP pada WIUP yang berada dalam satu wilayah kabupaten/kota, menjadi kewenangan pemerintah daerah kabupaten/kota.

Lebih lanjut, pada UU Pemda 2014, Pasal 13 ayat (1) mengenal beberapa prinsip-prinsip yang digunakan dalam penyelenggaraan urusan pemerintahan. Prinsip-prinsip tersebut adalah prinsip akuntabilitas, prinsip efisiensi dan prinsip eksternalitas. Ketiga prinsip tersebut bertitik berat bahwa penyelenggara suatu urusan pemerintahan ditentukan berdasarkan efisiensi dan dampak yang timbul dari suatu urusan tersebut. Berdasarkan ketiga prinsip tersebut untuk 
IUP pada WIUP di satu kabupaten/kota seharusnya diselenggarakan oleh pemerintah daerah kabupaten/kota.

Dalam rangkaian implementasi UU Pemda 2014, Menteri ESDM mengeluarkan Surat Edaran Menteri ESDM No.04.E/30/DJB/2015 Tentang Penyelenggaraan Urusan Pemerintahan di Bidang Pertambangan Mineral dan Batubara Setelah Berlakunya UU Nomor 23 Tahun 2014 Tentang Pemerintahan Daerah. Dalam buku "Pedoman Penyusunan dan Bentuk Tata Naskah Dinas Departemen Kehakiman Republik Indonesia”, surat edaran adalah naskah dinas yang memuat petunjuk tentang hal-hal yang harus diperhatikan dan dilakukan berdasarkan peraturan/ketentuan yang ada. Surat edaran bersifat umum dan berlaku tetap. Sebagai suatu bentuk peraturan kebijakan surat edaran tidak mengikat secara hukum (wetmatigheid). Peraturan kebijakan bukan peraturan perundang-undangan meskipun menunjukkan sifat atau gejala sebagai peraturan perundang-undangan. Sebagai peraturan yang bukan merupakan peraturan perundang-undangan, peraturan kebijakan tidak secara langsung mengikat secara hukum, tetapi mengandung relevansi hokum (Bagir Manan, 1997: 172). Dilihat dari karakteristik Surat Edaran sebagai Peraturan Kebijakan, maka SE Menteri ESDM No.04.E/30/DJB/2015 tidak dapat digunakan sebagai dasar yang mengalahkan peraturan perundang-undangan dalam pengaturan wewenang penerbitan IUP, namun hanya sebagai petunjuk pelaksana.

3. Konsekuensi Hukum Pengelolaan Pertambangan Mineral dan Batubara Pasca Berlaku Undang-Undang Nomor 23 Tahun 2014 Tentang Pemerintahan Daerah

Pemberlakuan UU Pemda 2014 secara konsisten menampakan ekspresi sentralisme penyelenggaraan pemerintahan ketika merumuskan ketentuanketentuan mengenai penyerahan kewenangan (desentralisasi). Secara umum, UU Pemda 2014 menarik secara signifikan kewenangan di bidang pengelolaan SDA ( Yeli Meivi Dapu, 2016: 70).

Saat ini Pemerintahan Daerah mengalami implikasi dalam segala bidang, salah satunya adalah pelayanan terhadap masyarakat terkait tata kelola 
pertambangan mineral dan batubara. Peraturan perundangan tersebut belum memiliki regulasi teknis sehingga mempengaruhi sistem, tata kelola dan urusan pemerintahan dalam penyelenggaraan pemerintahan, baik Pemerintah Daerah Provinsi maupun Pemerintah Daerah Kabupaten/ Kota. Selain berdampak pada perubahan kewenangan pengelolaan bidang pertambangan minerba, juga berdampak terhadap organisasi perangkat daerah yang melaksanakan urusan tersebut.

Konsekuensi hukum terhadap penerapan UU Pemda 2014 setidaknya mempengaruhi beberapa urusan kewenangan di bidang ESDM pada Pemerintahan Daerah seperti:

a. Kelembagaan

Setelah kewenangan Pemerintah Daerah Kabupaten/ Kota dalam hal pengelolaan ESDM menjadi hapus, maka berdampak bagi hapusnya juga Dinas Pertambangan dan Energi yang berada di Pemerintah Kabupaten/ Kota. Kelembagaan Pertambangan dan Energi hanya ada di Pemerintah Daerah Provinsi. Selanjutnya Kelembagaan yang ada di Pemerintah Daerah Kabupaten/Kota berganti status menjadi cabang dinas atau UPTD Provinsi. Dengan demikian perlu pengaturan pemindahan P3D (personil, pembiayaan, sarana dan prasarana, dan dokumen).

b. Serah Terima Personil, Pendanaan, Sarana dan Prasarana, dan Dokumen (P3)

Ketentuan Pasal 404 UU Pemda 2014 juga membahas tentang P3D, dijelaskan“Serah terima personel, pendanaan, sarana dan prasarana, serta dokumen sebagai akibat pembagian Urusan Pemerintahan antara Pemerintah Pusat, Daerah provinsi dan Daerah kabupaten/kota yang diatur berdasarkan Undang-Undang ini dilakukan paling lama 2 (dua) tahun terhitung sejak UndangUndang ini diundangkan”. Pada Tahap transisi dilakukan melalui mekanisme tugas pembantuan dari Pemerintah Daerah Provinsi ke Pemerintah Daerah Kabupaten/Kota. 
Pengalihan personil sebaiknya segera dilakukan, karena apabila tidak dilakukan maka dapat timbul keresahan di kalangan Pegawai Negeri Sipil (PNS) Daerah yang berdasarkan UU Pemda 2014 sudah tidak memiliki tempat untuk menjalankan tugas dan fungsinya. Padahal menurut undang-undang tentang Aparatur Sipil Negara (ASN), PNS diangkat dalam jabatannya dan pangkat tertentu dalam instansi pemerintahan. Apabila tidak segera dilaksanakan pengalihan maka berpotensi menimbulkan kerugian bagi PNS yaitu PNS tersebut tidak menerima gaji karena tidak berada dalam satuan kerja manapun.

Selanjutnya terkait pendanaan, Setelah berlaku UU Pemda 2014 maka keajiban penganggaran bisang ESDM menjadi kewenangan Pemerintah Daerah Provinsi. Bantuan keuangan PemerintahPusat kedepannya hanya diperuntukkan bagi Pemerintahan Daerah Provinsi.

Hal lain yang perlu diperhatikan adalah penyerahan sarana dan prasarana. Pelaksanaannya mengacu pada kepada Peraturan Pemerintah Nomor 27 Tahun 2014 tentang Pengelolaan Barang Milik Negara/ Daerah Bab IX tentang pemindahtanganan. Bentuk pemindatanganan dapat berupa penjualan, tukar menukar, hibah, dan penyertaan modal pemerintah pusat/ daerah. Dalam rangka pengalihan aset antara Pemerintah Pusat dan Pemerintah Daerah maka mekanisme yang dimungkinkan adalah hibah.

c. Perubahan Peraturan

Perijinan terkait energi dan sumber daya mineral akan beralih ke Pemerintah Daerah Provinsi. Perijinan harus diatur oleh Norma, Standar, Prosedur dan Kriteria (NSPK) yang jelas. Untuk melaksanakan pelayanan publik yang maksimal maka dikeluarkanlan beberapa peraturan yang menjadi dasar pedoman pelaksanaan pengelolaan ESDM sub urusan pertambangan mineral dan batubara yaitu: 
1) Surat Sekretaris Jenderal ESDM Nomor 2115/30/SDB/2014 tanggal 16 Desember 2014, perihal Kewenangan Pengelolaan Pertambangan Mineral dan Batubara.

2) Surat Edaran Menteri Dalam Negeri tanggal 16 Januari 2014 tentang Penyelenggaraan Urusan Pemerintah Setelah Ditetapkan UndangUndang Nomor 23 Tahun 2014 tentang Pemerintahan Daerah.

3) Surat Direktur Teknik dan Lingkungan Nomor 1116/37.02/DBT/2015 tanggal 13 April 2015 perihal Pengawasan Kegiatan Pertambangan di Kabupaten/Kota.

4) Surat Edaran Direktur Jenderal ESDM Nomor 04.E/30/DJB/2015, tanggal 30 April 2015 tentang Penyelengaraan Urusan Pemerintahan di Bidang Pertambangan Mineral dan Batubara Setelah Berlakunya Undang-Undang Nomor 23 Tahun 2014 tentang Pemerintahan Daerah.

Secara garis besar berlakunya Undang-Undang No. 23 tahun 2014 tentang Pemerintahan Daerah, maka Pemerintah Kabupaten/Kota tidak memiliki kewenangan dalam hal membentuk struktur satuan kerja perangkat daerah (Dinas Pertambangan), menyusun peraturan daerah (Perda) yang berhubungan dengan pertambangan, dan penerbitan izin usaha pertambangan (IUP) dan izin usaha pertambangan rakyat (IUPR) Dengan demikian menunjukkan bahwa dalam pelaksanaan UU Pemda 2014 terutama pengelolaan pertambangan minerba dan batubara menunjukkan adanya kecenderungan menarik kembali atau resentralisasi kewenangan Pemerintah Daerah Kabupaten/Kota oleh Pemerintah Pusat melalui parantara Pemerintah Provinsi yang memang menjadi perpanjangan tangannya. Selain itu, juga menunjukkan adanya beberapa overlaping regulasi antara undang-undang sektoral (UU No. 4 tahun 2009 tentang Pertambangan Mineral dan Batu Bara) dengan UU No. 23 tahun 2014 tentang Pemerintahan Daerah. Sehingga perlunya melakukan revisi terhadap berbagai prodak hukum yang saling mengalami kontradiksi. 


\section{Simpulan}

1. Secara normatif politik hukum pengelolaan sumber daya alam di Indonesia sudah ditentukan dalam Pasal 33 ayat (2) dan ayat (3) UUD 1945. Lebih lanjut pengaturan terkait pengelolaan pertambangan mineral dan batubara diatur dalam Undang-Undang Sektoral yaitu Undang-Undang Nomor 4 Tahun 2009 tentang Pertambangan Mineral dan Batubara, dimana UndangUndang tersebut telah menyesuaikan dengan Undang-Undang Nomor 32 Tahun 2004 tentang Pemerintahan Daerah terkait kewenangan pengelolaan pertambangan mineral dan batubara, yang saat ini sudah dicabut dan digantikan dengan Undang-Undang Nomor 23 Tahun 2014 tentang Pemerintahan Daerah. Sehingga terjadi disharmonisasi aturan perundangundangan sektoral (Undang-Undang Nomor 4 Tahun 2009 tentang Pertambangan Mineral dan Batubara) yang kontradiktif dengan UndangUndang Nomor 23 Tahun 2014 tentang Pemerintahan Daerah, terkait kewenangan Urusan Pemerintahan Konkuren dalam hal pengelolaan sumber daya alam pertambangan mineral dan batubara.

2. Pemberlakukan UU No. 23 Tahun 2014 tentang Pemerintahan Daerah berdampak pada sistem pemerintahan di Daerah. Pasca berlaku UndangUndang tersebut Pemerintah Daerah Kabupaten/ Kota tidak lagi memiliki kewenangan menyelenggarakan urusan pemerintahan Konkuren bidang Energi dan Sumber Daya Mineral (ESDM). Praktis Pemerintah Daerah Kabupaten/ Kota tidak lagi berwenangan dalam membuat Perda, Menerbitkan Izin Pertambangan mineral dan batubara (kecuali panas bumi), serta pembinaan dan pengawasan bidang ESDM . Sehingga mengakibatkan konsekuensi hukum bidang Energi dan Sumber Daya Mineral sub urusan pertambangan mineral dan batubara pasca berlaku Undang-Undang Nomor 23 Tahun 2014 tentang Pemerintahan Daerah, yaitu perubahan kelembagaan bidang ESDM, serah terima Personil, Pendanaan, Sarana Prasaran dan 
Dokumen (P3D), dan perubahan peraturan perundangan yang berkaitan dengan pengelolaan pertambangan mineral dan batubara.

\section{E. Saran}

1. Kebijakan pengelolaan pertambangan yang tertuang dalam Undang-undang Nomor 4 Tahun 2009 tentang Pertambangan Mineral dan Barubara berserta turunannya perlu dilakukan perubahan yang disesuaikan dengan kebijakan pengelolaan pertambangan mineral dan batubara sebagai implementasi UU Nomor 23 Tahun 2014 tentang Pemerintahan Daerah.

2. Segera dibentuk Peraturan Pemerintah mengenai teknis pelaksanaan Undang-Undang Nomor 23 Tahun 2014 tentang Pemerintahan Daerah. Karena pengaturan lebih lanjut dari suatu norma yang ada dalam undangundang dengan menggunakan surat edaran sangatlah tidak biasa. Terlebih surat edaran bukan merupakan produk peraturan perundang-undangan meskipun surat edaran termasuk dalam kategori salah satu instrumen peraturan kebijakan.

\section{F. Daftar Pustaka}

AA. Oka Mehendra. 2013. "Harmonisasi Peraturan Perunadang-Undangan" Jurnal Hukum Perancangan Peraturan Perundang-Undangan. Vol.1. No. 1 .

Armen Yasir. 2007. Hukum Perundang-undangan, Unila, Bandar Lampung.

Bagir Manan. 1997. Beberapa Masalah Hukum Tata Negara Indonesia. Bandung: PT. Alumni.

. 2004. Hukum Positif Indonesia: Suatu Kajian Teoritik. Yogyakarta: FH UII Press.

Gatot Supramono. 2012. Hukum Pertambangan Mineral dan Batu Bara di Indonesia. Jakarta: Rineka Cipta. 
Hassan Shaddly, dkk,. 1980. Ensiklopedi Indonesia, Ichtisar Baru-Van Hoeve, Jakarta.

L.M. Gandhi, "Harmonisasi Hukum Menuju Hukum yang Responsif”. Orasi Ilmiah. Pengukuhan Jabatan Guru Besar Tetap pada Fakultas Hukum Universitas Indonesia, (Jakarta, 14 Oktober 1995).

Lili Romli. 2007. Potret Otonomi Daerah dan Wakil Rakyat di Tingkat Lokal. Yogyakarta: Pustaka Pelajar.

Mohammad Zamroni. 2015. " Menakar Korelatifitas Antara Harmonisasi Peraturan Perundang-Undangan”. Jurnal Rech Vinding. Vol.1. No.1.

Peter Mahmud Marzuki. 2014. Penelitian Hukum. Jakarta: Prenadamedia Group.

Salim H.S. 2014. Hukum Pertambangan Indonesia. Ctk. Ketujuh, Ed. Revisi, PT. Raja Grafindo Persada, Jakarta.

Victor Imanuel. 2012. "Hak Menguasai Negara Atas Mineral dan Batubara Pasca Berlakunya Undang-Undang Minerba”. Jurnal Konstitusi. Vol.9. No. 3.

Yeli Meivi Dapu.2016. "Implikasi UU No.23 Tahun 2014 Terhadap Kewenangan Urusan Pemerintahan”. Jurnal Lex Et Societatis. Vol. 4. No. 8. 